Ganna DUGINETS, Hossain Z. OMRAN

\title{
INSTITUTIONAL SUPPORT OF UKRAINE'S FOREIGN TRADE: THE CONTEXT OF THE MIDDLE EAST
}

\begin{abstract}
Conceptual approaches to stimulating trade cooperation of Ukraine and the Middle East countries are investigated. The paper determines the existent potential for furthering cooperation in the region and outlines its main prospects. The current system of institutional support of Ukraine's foreign trade is analysed. In light of the worsening economic conditions in the world and falling indicators of export potential in Ukraine in 2019 and 2020, development and implementation of institutional support for the strategy of promoting domestic goods on foreign markets and supporting their production becomes a priority. The authors substantiate the main factors that should be taken into account by Ukrainian producers when entering the Middle East markets. An hierarchy of institutional support goals is suggested in terms of Ukraine's cooperation with the countries of the region in foreign trade.
\end{abstract}

(C) Ganna Duginets, Hossain Z. Omran, 2021.

Duginets, Ganna, Doctor of Economic Sciences, Professor, Head of the Department of World Economy, Kyiv National University of Trade and Economics, Ukraine. ORCID: 0000-0003-3708-3666 Email: g.duginets@knute.edu.ua.

Omran, Hossain Zonfali, PhD student, Iran, Kyiv National University of Trade and Economics. ORCID: 0000-0002-8227-0607 Email: h.omran@knute.edu.ua. 


\section{Key words:}

institutional support; trade cooperation; stimulation of export; Ministry of International Affairs; the Middle East countries.

JEL: E65, F10.

5 figures, 2 tables, 29 references.

\section{Problem Statement and Topicality}

The global pandemic that began at the end of 2019 and the strategic competition between the world's leading countries are increasingly leading to decentralization of trade. Given that the limited measures taken in response to the pandemic have reduced the number of economic interactions, resulting in significant economic losses, governments and NGOs need to pursue policies to support the liquidity of economic actors to ensure a smooth economic recovery while stabilizing the macroeconomic situation. This presents an opportunity to develop trade relations not only with regular partners, but also to establish ties with new countries. In these conditions, the institutional system of foreign trade, which is represented by a system of interacting governmental and non-governmental institutions, is a priority of economic policy in most countries.

Socio-economic development of the Middle East countries differs significantly, but they can be divided into three main groups: oil exporters, developing oil countries and oil-importing countries. The general trend for the region in recent years is a gradual strengthening of economic growth, after the slow growth observed in the post-crisis period (Mashal, 2012). Taking into account the geographical proximity of the Middle East markets and their potential capacity, the Government of Ukraine should pursue a strategy of cooperation with this region that promotes the strengthening of bilateral and multilateral trade, in particular through providing it with institutional support. The importance of this area of cooperation is also evidenced by the data of analytical reports for the last year. For 
instance, in July-December 2019/2020, a total of 6.3 million tons of grain crops (wheat, barley, corn) were exported from Ukraine to the Middle East. This volume accounts for almost $21 \%$ of total grain exports from Ukraine during the reporting period (30.5 million tons). In addition, the figure is $70 \%$ higher than the volume of exports to the Middle East for the same period last season (3.7 million tons) (Kupchnko \& Rozhko, 2020). These goods actually form the basis of the commodity structure of Ukraine's foreign trade with the region; however, the realities of the third decade of the $21^{\text {st }}$ century encourage countries to achieve parity trade in goods and services with high value added. Such parity will be difficult to achieve without improving the institutional support of Ukraine's foreign trade.

The aim of the article is to identify and analytically substantiate the institutional support and stimulation of Ukraine's foreign trade cooperation, using the Middle East countries as an example partner.

\section{Literature Review}

Leading scientific schools have formed a fairly broad terminological apparatus for defining the foreign trade strategy of the state, as well as areas and tools to stimulate trade cooperation, which can change the sectoral structure of the state's economy to achieve economic growth based on optimization of management and productivity.

The issue of the effectiveness of export support by the state is regularly studied by experts from the International Monetary Fund, the World Bank, a number of think tanks in the United States and Western Europe. Research on the relationship between export promotion policies and further economic growth is also noteworthy. We can highlight the research of D. Santosa (2018) on five ASEAN countries, the study of D. Wnukowski (2016) on the experience of Expert Promotion Agencies in the UK, Hungary and the Czech Republic and the work of A. Éltető and K. Antalóczy (2017) on state policy to promote trade and relevant institutions in the Baltic States, Visegrad and Iberia. Ukrainian scholars have also studied this topic extensively. Namely, O. Kamianetska (2016) has investigated the system of state support for exporters in developed countries, A. Mazaraki (2018) has studied the institutional framework for supporting the export of domestic producers, while O. Sharov (2019) has analysed the general theoretical issues of economic diplomacy as a science of international economic relations and a means of implementing foreign economic policy.

In foreign literature, many scientists have devoted their works to the study of economic development in the Middle East. For example, M. Abdouli and S. Hammami (2020) have explored the relationship between economic growth, foreign direct investment (FDI), environmental quality and financial development 
in the Middle East and have concluded that there is a correlation between financial development and the size of $\mathrm{CO} 2$ emissions. Further, the results obtained by B. Muhammad (2019) in a study on the relationship between economic growth in developed countries and the Middle East on one side and energy consumption and $\mathrm{CO} 2$ emissions on the other are quite interesting. The author recommends the countries of the region to implement strategies that focus on propagating environmentally friendly technologies to reduce $\mathrm{CO} 2$ emissions. The relevance of these studies confirms that the countries of the region are following the trend of global transformations in their development, namely they are emphasizing the environmental factor of socio-economic development. It should be noted that research at the end of the twentieth century paid more attention to the factors of economic development of countries in the region based on exports of raw materials and semi-finished products with low value added (related to oil), such as rubber and plastics, food and chemical goods and semi-finished products. As a result, this region, along with sub-Saharan Africa, is less industrialized than any other developing region (Askari, 2017). Lastly, a separate group in the research is made up of studies on the relationship between economic development and political reform, institutional support for foreign trade, etc. (Glasser, 2001; Metcalfe \& Mimouni, 2011; Milton-Edwards, 2018).

Most of the works of Ukrainian scientists are devoted to identifying problems, prospects and possible areas of cooperation between Ukrainian enterprises and the Middle East countries in the fields of trade and economics (Bohomolov et al., 2020; Bohorodytsk et al., 2020; Nebaba \& Kolpina, 2020; Omar, 2013; State Institution «Export Promotion Office of Ukraine», n.d.; Mazaraki et al., 2014; Hasan, 2018; Mazaraki et al., 2018).

Acknowledging the significant contribution of existing studies in this area of research, nevertheless, we must point out another aspect that should be taken into account when shaping nation foreign policy - identification of the peculiarities of stimulating trade cooperation between Ukraine and other countries, such as the Middle East states. The first foreign visit of the President of Ukraine in 2021 only confirms the topicality of this article's direction of research.

\section{Research Methods}

The study uses a set of complementary methods of scientific identification of economic processes and phenomena: system-structural approach, comparative and statistical analysis, as well as information, process and institutional approaches. The goal tree approach was used to substantiate the strategy of improving the institutional support of Ukraine's foreign trade in the context of cooperation with the Middle East, taking into account the patterns of target setting and principles of forming hierarchical goal structures. The hierarchy of goals was de- 
veloped using the method of decomposition to update the existent strategy. The primary data for the study consisted of the current legal framework and official publications of the State Statistics Service of Ukraine, while secondary sources included monographic studies and papers of domestic and foreign scientists published in specialized literature.

\section{Research Results}

\section{Trends in the development of Ukraine's foreign trade}

In order to identify the peculiarities of stimulating trade cooperation of Ukraine with other countries, basic indicators that characterize tendencies in foreign trade of the state must be analysed (fig. 1).

\section{Figure 1}

Volumes of Ukraine's exports of goods and services from 2005 to 2020, million USD

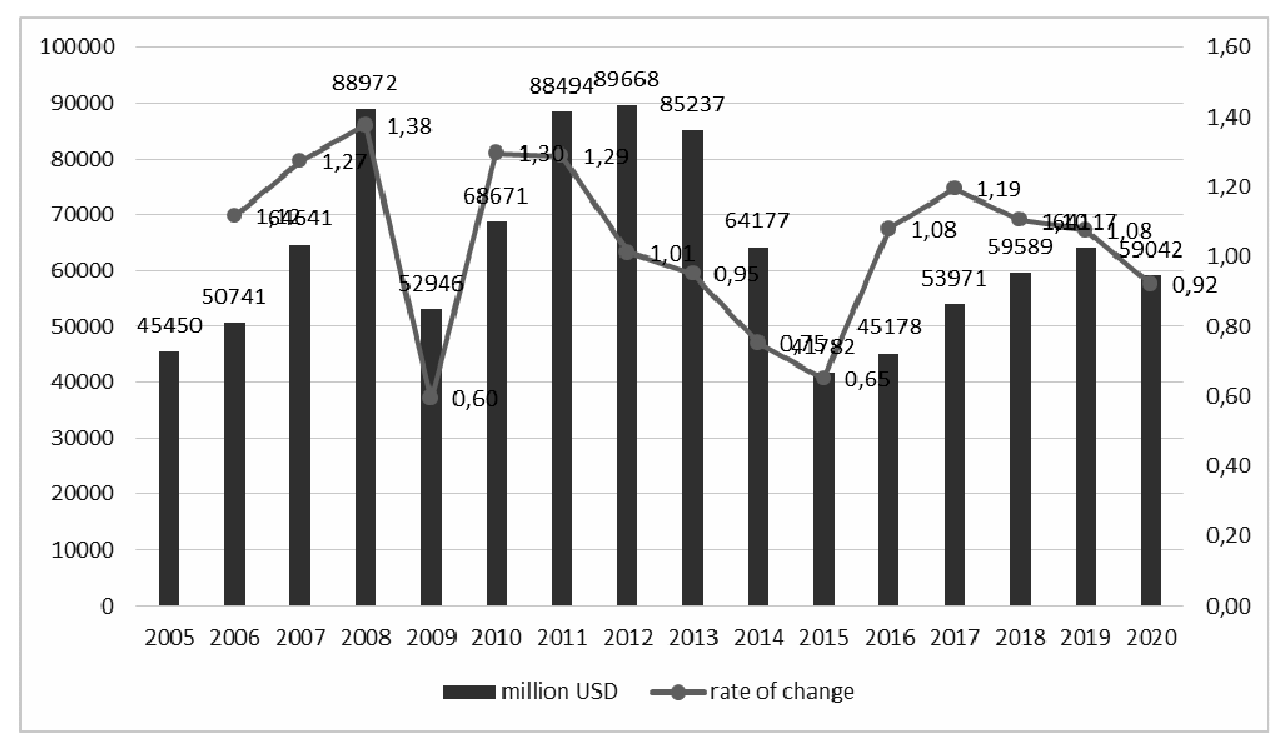

Source: State Statistics Service of Ukraine. (n.d.). http://www.ukrstat.gov.ua 
As the figure shows, Ukraine's exports of goods and services had a general upward trend during the period from 2005 to 2012. In particular, the value of this indicator increased by $98 \%$ if we compare 2019 to 2005 . However, Ukraine's exports decreased by $102 \%$ from 2012 to 2015 due to the effects of the economic crisis. In 2016-2019, Ukraine's exports volumes stabilized from and returned to marginal growth. In 2017, compared to the previous year, Ukrainian exports increased by $19.0 \%$, in 2018 - by $9.4 \%$, in 2019 - by $5.7 \%$. Meanwhile, in 2020, exports of goods and services decreased by almost 8\% compared to 2019 . (State Statistics Service of Ukraine, n.d.). Authors believe that this was caused by the reduction in business activity precipitated by the global pandemic.

Moreover, the indicators of exports of goods and services by major trading partners for 2018-2020 show that Ukraine has been diversifying its export destinations over the past 5 years (Fig. 2). Only exports to the EU consistently ranked first in volume over the past 5 years, and accordingly were excluded from this infographic.

Figure 2

Ukraine's main trading partners in exports of goods and services, percent

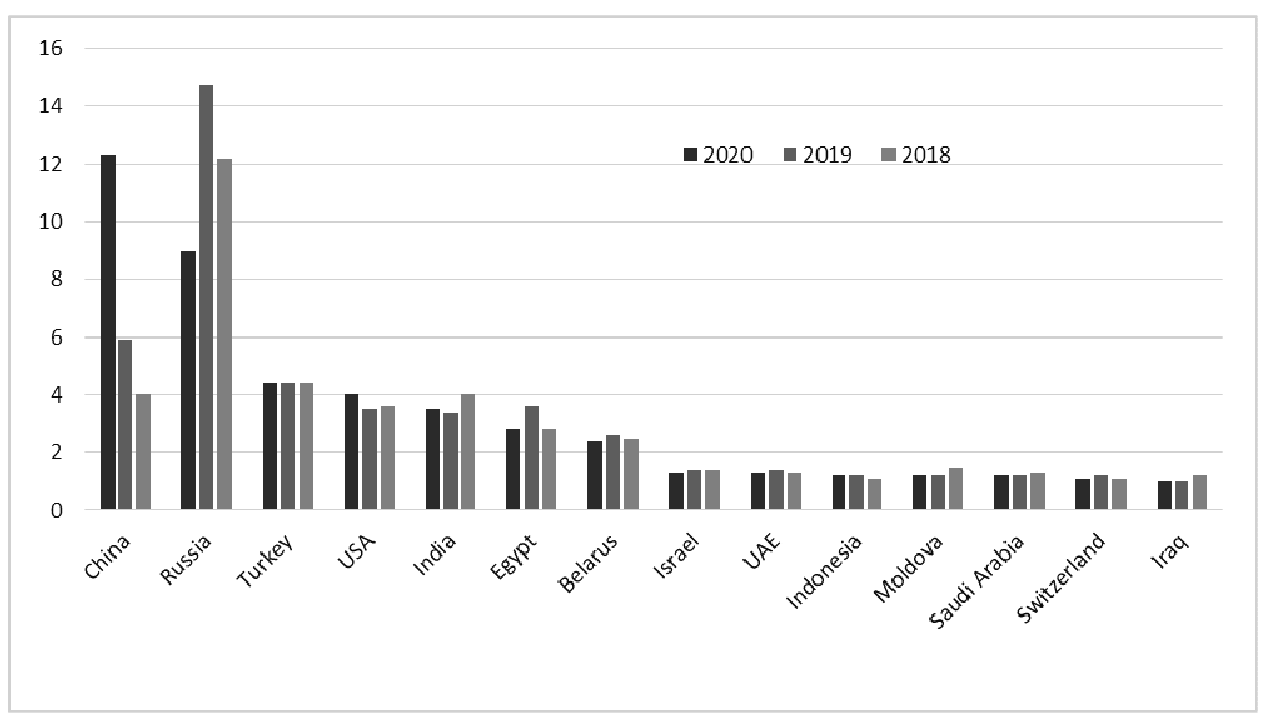

Source: created by the authors using the data of State Statistics Service of Ukraine. (n.d.). http://www.ukrstat.gov.ua 

the context of the Middle East

The analysis of the data shown in Figure 2 clearly indicates that the shares of Turkey, Egypt, Israel, UAE, Saudi Arabia and Iraq remained steady among the main consumers of Ukrainian goods and services. Diversification of the export market reflects changes in Ukraine's export products. Traditionally, the shares of agricultural goods and ferrous metals in exports to these countries were roughly equal, covering around $40-45 \%$. However, in recent years, the share of metals has fallen to $20 \%$ with regards to some countries, while agricultural exports have risen to almost $60 \%$. For example, grain exports to Israel average $44 \%$ and ferrous metals $-27.06 \%$ of Ukrainian exports to this country, for Egypt these figures have an average of $42 \%$ and $60.59 \%$, and for Saudi Arabia - 50\% and $28.45 \%$, respectively. Meanwhile, it should be noted that there are almost no innovative products in the structure of Ukrainian exports to the Middle East (State Statistics Service of Ukraine, n.d.).

Additionally, it is necessary to take into account two factors while developing and substantiating areas of cooperation with the Middle East: firstly, the consequences of the global pandemic, and secondly, the spread of political conflicts over the past two years, which periodically turn into military confrontation («ISIS», «Al Qaeda», «Taliban», «Hamas», etc.). These may have a deeper and lasting impact on the economies of the region than previous recessions. This can be explained by the fact that the unique features of the global shock caused by the pandemic have superimposed on long-term vulnerabilities in the region. Thus, a significant share of the service sector (including tourism) in the region's economy, deteriorating balance sheets of enterprises, limited opportunities to work remotely and dependence on remittances will seriously constrain the prospects for recovery. As a result, the region is projected to record a decline in real GDP of $4.1 \%$ in 2020. This reduction is 1.3\% over the forecast from April 2020. With the global economic recovering slowly, the risks of deterioration prevail, while the pandemic continues to put the region to the test. According to preliminary forecasts, Ukrainian economy is expected to experience a $5 \%$ fall in GDP in 2020. GDP reduction in the IV quarter will amount to 2.5-3.0\% (State Statistics Service of Ukraine, n.d.). Economic factors of national interests are a source of social welfare and ensure the development and prosperity of the state; therefore, all countries consider them while setting current foreign policy priorities. Consequently, the strategy for expanding markets and effectively supporting domestic business abroad must be continuously updated.

\section{Growing influence of the diplomatic factor on the development of Ukraine's foreign trade}

First pieces of legislation that must be taken into consideration when discussing the features of stimulating trade cooperation of Ukraine with other countries are the Orders of the President No. 841/1996 and No. 1188/2005, which 
placed the responsibility for coordinating all government actions in the field of foreign relations on the Ministry of Foreign Affairs of Ukraine.

The Ministry of Foreign Affairs approves all aspects official events where Ukraine is represented abroad - from the members of an official delegation to defending Ukrainian interests in court proceedings on an anti-dumping case initiated by a foreign state with regards to Ukrainian goods. In practice, this means that none of the official documents prepared by the Ministry of Economic Development, Trade and Agriculture, the National Bank, the Ministry of Finance of Ukraine or any other public authority can be proposed to foreign partners without the consent of the Ministry of Foreign Affairs.

Order of the President of Ukraine No. 522/2010 of April 8, 2010 «On some aspects of representing economic interests of Ukraine abroad» provides for the creation of economic departments subordinated to the Ministry of Foreign Affairs within the structure of Ukrainian institutions abroad. Order of the President of Ukraine No. 837 of November 8, 2019 «On urgent measures to conduct reforms and strengthen the state" envisions strengthening the institutional capacity of the diplomatic service to facilitate the activities of Ukrainian economic actors abroad.

Thus, the analysis of existing regulations indicates clear prerequisites for stimulating trade cooperation, so there is no need to adopt new acts. It is simply necessary to approve the transfer of the foreign economic department of the Ministry of Economic Development, Trade and Agriculture of Ukraine under the authority of Ministry of Foreign Affairs, which can be done by a decision of the Cabinet of Ministers of Ukraine.

Based on the aforementioned list of regulations and the exclusive role of the Ministry of Foreign Affairs in coordinating measures to support exporters, it is necessary to identify the important areas of decisions and actions by authorities that are coordinated with the Ministry of Foreign Affairs (Fig. 3).

Diplomatic support for domestic exporters is one of the most important activities of the Ministry of Foreign Affairs aimed at expanding the markets and ensuring sectoral diversification of domestic export.

Since April 2013, the Exporters and Investors Council has operated under the Ministry of Foreign Affairs to ensure implementation of national priorities, promote Ukrainian exporters on foreign markets, protect their economic interests abroad and attract foreign direct investment into Ukraine's economy. The Council constantly monitors and promptly informs domestic producers about the potential opportunities to expand Ukraine's share in foreign markets, the interest of foreign companies in establishing contacts with domestic partners. 


\section{Figure 3}

Decisions and actions of executive bodies in the field of export activities approved the Ministry of Foreign Affairs

Decisions and actions of executive bodies in the field of export activities approved the Ministry of Foreign Affairs

$\begin{aligned} & \text { initiating foreign visits of Ukrainian officials or inviting foreign official } \\ & \text { delegations }\end{aligned}$
a

preparing speeches, official statements and initiatives of international scale on the development of Ukraine's foreign trade

conducting international consultations and negotiations related to the implementation of the state policy of Ukraine in the field of export stimulation

drafting international bilateral or multilateral documents, regardless of their name (treaty, convention, agreement, protocol, communiqué, annex to the protocol, etc.)

$\square$ participating in international conferences, sessions of international organizations, meetings of intergovernmental committees and other bodies

Source: created by the authors using the data of (Ministry of Foreign Affairs of Ukraine, n.d.; Order of the President of Ukraine No. 522/2010; Order of the President of Ukraine No. 837)

On behalf of the Ministry of Foreign Affairs, the Council has been granted certain powers in order to execute its functions, particularly facilitate the access of domestic exporters to the world markets (Fig. 4).

The practical guidebook of the Council outlines a mechanism for processing applications of domestic companies to promote their products and search for partners in foreign markets using the available capabilities of economic departments within foreign diplomatic missions.

At the same time, one of the key tasks of the Council is to promote the participation of Ukrainian enterprises and companies in tenders and competitions, as well as the implementation of infrastructure and investment projects abroad and participation in exhibitions and forums. This contributes to the development of international production cooperation of Ukrainian enterprises, increasing the volume of Ukrainian exports and promotion of the commercial interests of our companies in world markets in general. 
Figure 4

Exporters and Investors Councils' powers to develop and implement state policy aimed at facilitating exporters' entry into the foreign markets

Exporters and Investors Councils' powers to develop and implement state policy aimed at facilitating exporters' entry into the foreign markets

give official clarifications on the direction of Ukrainian foreign policy
$\begin{aligned} & \text { receive information on activities in the field of foreign relations, in particular } \\ & \text { with regards to participation in international organizations and their bodies } \\ & \text { and implementation of international agreements, in the prescribed manner } \\ & \text { from the executive bodies }\end{aligned}$
$\begin{aligned} & \text { make proposals on increasing the efficiency of executive bodies in the field } \\ & \text { of foreign relations, including the participation of executive bodies in the } \\ & \text { activities of international organizations and their bodies in the prescribed } \\ & \text { manner }\end{aligned}$

Source: created by the authors using the data of (Ministry of Foreign Affairs of Ukraine, n.d.; Order of the President of Ukraine No. 522/2010; Order of the President of Ukraine No. 837)

In this regard, foreign diplomatic missions of Ukraine provide the necessary information support for the participation of Ukrainian companies in international projects, as well as conduct the relevant work on a regular basis. In addition to providing direct assistance to Ukrainian producers in promoting their products on foreign markets, the Ministry of Foreign Affairs, together with foreign diplomatic missions, on a regular basis provides information and instruction abroad to promote the investment potential of Ukraine.

\section{Diversification of Ukraine's foreign trade through the Middle East countries}

Given Ukraine's position in the world economy and its geographical location, the integration of our country into the EU also provides for the creation of additional opportunities for the development of economic relations with other countries and regions of the world. Therefore, the economic region of the Middle East can be seen as a priority for the several reasons. 

the context of the Middle East

First, The Middle East is important for the European Union as a growing market and supplier of products, including competitively priced high-tech products, as well as a region for profitable investment. In this context, the geographical location of Ukraine makes it an important transit centre (hub) in the system of economic relations between Europe and the Middle East.

Second, bearing in mind the strategic development of foreign economic relations, we must consider that the Middle East market is important not only in itself, but also as a potential platform for Ukraine entering (expanding its share) in other markets, namely:

- Central Asia (via Iran);

- Africa (via Egypt);

- the Americas (via the Gulf countries).

Third, the Middle East, due to its rapid economic development, is improving its standing on the international economic arena. This determines the longterm prospects for Ukrainian producers entering this market.

Fourth, the analysis of Ukraine's trade with other countries in 2019-2020 has shown that the ratio of import/export coverage in terms of the Middle East countries is 2.6 (2.5 billion USD in absolute). It also determined that Ukraine does not have a negative foreign trade balance with any of the countries that are part of this region, which has a positive impact, primarily on the balance of payments and GDP. According to the report of the NGO «Ukrainian Prism», in 2019, the trade turnover with the Middle East (excluding the main partners of Israel, Turkey, and Iran) amounted to 7.1 billion dollars, of which exports amounted to 6.6 billion dollars, which indicates a significant positive balance. This is $13.2 \%$ of Ukraine's total exports (Bureiko et al., 2020). As mentioned before, Ukraine's main trading partners in 2020 were Egypt, Saudi Arabia and the UAE, with the trend towards increasing trade volumes. According to NISS experts, the economic presence should be further increased primarily in priority areas, which can be determined by the urgency of local needs and the availability of corresponding potential in Ukraine. In other words, export as many goods / services as possible, import as few problems as possible (Bohomolov et al., 2020).

Meanwhile, research conducted by the NGO «Ukrainian Prism» proves that a number of factors have a negative impact on the promotion of Ukrainian exports in this region (Bureiko et al., 2020). Thus, according to experts, the Middle East did not appear in key foreign policy documents of Ukraine until 2020. The region was mentioned in the Military Doctrine of Ukraine (2015) only in a broad security context and in the Export Strategy (2017), which referred to individual countries - Egypt, Saudi Arabia, UAE, Lebanon - as promising markets. The lack of a clearly defined regional foreign policy strategy also has a negative impact on the development of trade cooperation. The Order of the President of Ukraine No. 837/2019 «On urgent measures to conduct reform and strengthen 
the state" makes no mention of the Middle East in the section on foreign policy (Bureiko et al., 2020). Thus, the imperfection of institutional support for the promotion of domestic exporters of goods and services is a serious problem that, along with corruption and the lack of financing for exporters (trade financing), complicates the implementation of any positive initiatives in this direction.

Ukraine, as a member of the WTO, must use only the mechanisms and procedures for financial support of export activities that are officially recognized by this organization. Therefore, the Law «On state financial support of export activities" was adopted in 2012, which was created to determine the principles of such state financial support. It aims to create favourable conditions for expanding the export potential of domestic economic entities, ensure the protection of Ukrainian exporters from the risk of non-payment and financial losses, and to increase the competitiveness of goods (works, services) of Ukrainian origin on world markets (Verkhovna Rada of Ukraine, 2012). It should be noted that among the normative documents governing the provision of export support in world practice are WTO provisions and the Agreement on Official Export Support of the OECD. The former include the General Agreement on Tariffs and Trade (GATT), Agreement on Subsidies and Countervailing Measures, and Agreement on Agriculture; the latter sets restrictions on the provision of official export support, including export loans and subsidies and coordinates with the WTO Agreement on Subsidies and Countervailing Measures.

Chief among Ukrainian institutions providing state support of exporters in accordance with the WTO regulations is the Ministry of Foreign Affairs, which is increasing its focus on facilitating the growth of Ukrainian exports in view of the current global trends and domestic economic conditions. Embassies of Ukraine abroad are being reorganized to provide practical assistance to domestic businesses entering foreign markets, and ambassadors increasingly play the role of intermediaries between domestic exporters and foreign counterparties. The functioning of the Exporters and Investors Council at the Ministry of Foreign Affairs of Ukraine was reorganized in this direction and a number of consultations between embassies and Ukrainian entrepreneurs were introduced. The first pilot project in this area was an online briefing with the participation of Ukrainian ambassadors to the Persian Gulf (Qatar, Kuwait, UAE and Saudi Arabia). The project involved about 50 stakeholders from various business sectors (Ministry of Foreign Affairs of Ukraine, 2020).

It should also be noted that the current «Export Strategy of Ukraine (roadmap for strategic trade development) for 2017-2021 » is not particularly effective (Order of the Cabinet of Ministers of Ukraine No. 1017-p). It contains useful conceptual provisions that, however, have not yet been implemented. Therefore, we propose to take into account the basic provisions of this document when outlining components of the strategy for entering the markets of the Middle East.

Given the aim of this article, we believe that the first step in substantiating the tools and mechanisms for institutional support of Ukraine's trade cooperation 
with other countries should consist of defining the mission, vision, goals and objectives, i.e. the ways of identifying the possible avenues for cooperation of Ukrainian producers with international partners. This step requires careful consideration of all results of the preliminary analysis, including the identified prospects and trends in foreign markets and Ukraine's export potential for the next 5 years. Therefore, we can identify several factors that must be taken into account when improving the institutional support of trade cooperation between Ukraine and the Middle East (Fig. 5).

Figure 5

Main factors to take into account when improving the institutional support of trade cooperation between Ukraine and the Middle East

$\begin{gathered}\text { Main factors that must be taken into account when improving } \\ \text { the institutional support of trade cooperation between } \\ \text { Ukraine and the Middle East }\end{gathered}$
\[ \begin{array}{c}\text { positive trend towards rapid acceleration of international trade between } \\ \text { Ukraine and the Middle East }\end{array} \]
\[ \begin{array}{c}\text { growing interest to the products of Ukrainian exporters in the Middle } \\ \text { Eastern markets }\end{array} \]
\[ \begin{array}{c}\text { the Middle East is important for the European Union as the fastest } \\ \text { growing market }\end{array} \]
the importance of the Middle East as a potential platform for Ukraine
entering (expanding its share in) neighbouring areas

The next step can involve the creation of a system of priorities to be used as a guide when shaping the strategy for promotion of Ukrainian producers in the Middle Eastern markets. Namely:

- given that the commodity structure of Ukrainian agricultural exports leans heavily towards raw materials, it should be diversified to strengthen the innovation component (e.g. joint research on breeding 
and varietal testing, development of technologies for growing crops, etc.);

- identification of possible avenues for expansion in competitive areas of cooperation (for example, participation in the program «Arab space» or implementation of projects of alternative energy sources);

- substantiation of promising areas should take into account the strong competitors (USA and Russia) on the Middle Eastern markets, as well as limited information in the countries of the region about the potential of Ukraine.

Thus, the main mission of institutional support for trade cooperation in the region is the transition of Ukrainian producers to the export of knowledgeintensive innovative products to the markets of the Middle East (Table 1). At the same time, there are several conditions of business activity that must be achieved, namely high standards of product quality, focus on consumer needs, staff motivation, openness to cooperation, and a practical approach to solving difficult situations.

Table 1

Characteristics of the strategy for promoting Ukrainian producers in the Middle Eastern markets

\begin{tabular}{|c|l|}
\hline $\begin{array}{c}\text { Time frame } \\
\text { for strategic } \\
\text { planning }\end{array}$ & \multicolumn{1}{|c|}{ Characteristics of the content } \\
\hline $\begin{array}{c}\text { Mission } \\
\text { strategy }\end{array}$ & $\begin{array}{l}\text { transition of Ukrainian producers to export of knowledge- } \\
\text { intensive innovative goods to ensure sustainable development } \\
\text { and successful entry into markets of the Middle East }\end{array}$ \\
\hline 1 year & $\begin{array}{l}\text { creation of necessary preconditions for the organization of finan- } \\
\text { cial support of Ukrainian commodity producers }\end{array}$ \\
\hline $2-3$ years & $\begin{array}{l}\text { creating favourable conditions that stimulate trade and innovation } \\
\text { for export diversification; developing business and trade support } \\
\text { services that can increase the competitiveness of enterprises, in- } \\
\text { cluding small and medium-sized enterprises }\end{array}$ \\
\hline 5 years & $\begin{array}{l}\text { improving the skills and competencies of enterprise workers, in } \\
\text { particular small and medium firms, necessary for participation in } \\
\text { international trade. }\end{array}$ \\
\hline
\end{tabular}

Source: created by the authors on the basis of the Order of the Cabinet of Ministers of Ukraine No. 1017-p. 
Next, we substantiate the main goals and objectives of the strategy, using the above provisions. It is worth noting that a system of strategy objectives should be formed first in accordance with the outlined strategy. To do this, it is advisable to use the goal tree approach. The method of decomposition is used to develop a hierarchy of goals in the process of updating the strategy. The process of defining the strategic goals using the proposed approach is outlined in Table 2. With this hierarchy of goals, strategies for entering the markets of the Middle East for Ukrainian producers are in a certain internal subordination.

Table 2

Definition of strategy goals for domestic producers entering the Ukrainian Eastern markets

\begin{tabular}{|c|c|c|c|}
\hline No. & $\begin{array}{l}\text { Directions of strategy } \\
\text { implementation }\end{array}$ & $\begin{array}{l}\text { Institutional } \\
\text { support for the } \\
\text { implementation } \\
\text { of goals }\end{array}$ & Expected results \\
\hline 1 & $\begin{array}{l}\text { Setting strategic goals of the 1st } \\
\text { level - creating conditions for fi- } \\
\text { nancial support of exporters }\end{array}$ & $\begin{array}{l}\text { Ministry of For- } \\
\text { eign Affairs of } \\
\text { Ukraine }\end{array}$ & $\begin{array}{l}\text { Specific strategic goals } \\
\text { of the highest level are } \\
\text { defined }\end{array}$ \\
\hline 2 & $\begin{array}{l}\text { Setting strategic goals of the } \\
\text { 2nd level: } \\
2.1 \text { regulatory support of the } \\
\text { strategy; } \\
2.2 \text { use of tariff and non-tariff } \\
\text { regulation mechanisms }\end{array}$ & $\begin{array}{l}\text { State Institution } \\
\text { «Export Pro- } \\
\text { motion Office } \\
\text { of Ukraine» }\end{array}$ & $\begin{array}{l}\text { Specific strategic goals } \\
\text { of the middle level are } \\
\text { defined }\end{array}$ \\
\hline 3 & $\begin{array}{l}\text { Strategic goals of the 3rd level: } \\
3.1 \text { strengthening the inte- } \\
\text { grated institutional framework } \\
\text { to stimulate innovation; } \\
3.2 \text { strengthening the innova- } \\
\text { tion potential of enterprises; } \\
3.3 \text { improving the legal and } \\
\text { economic conditions for trade. }\end{array}$ & $\begin{array}{l}\text { Ministry of For- } \\
\text { eign Affairs of } \\
\text { Ukraine, Ex- } \\
\text { porters and In- } \\
\text { vestors Council }\end{array}$ & $\begin{array}{l}\text { Levers and tools to in- } \\
\text { crease the efficiency of } \\
\text { the diplomatic functions } \\
\text { of the Ministry of For- } \\
\text { eign Affairs in the field } \\
\text { of facilitating the entry of } \\
\text { Ukrainian exporters into } \\
\text { the markets of the Mid- } \\
\text { dle East. }\end{array}$ \\
\hline
\end{tabular}

Preliminary strategic analysis and diagnostics of the development of each market (involving the study of internal and external factors) are important steps in improving the institutional support of Ukraine's foreign trade in any direction. It 
should be noted that this analysis must take into account the characteristics of the macroeconomic, political, legal, socio-cultural and technological environment in each country of a particular region.

\section{Conclusions and Prospects for Future Research}

The worsening world economic conditions caused by the global pandemic, on the one hand, and falling indicators of export potential in Ukraine in 2019 and 2020 , on the other, shine a spotlight on the importance of developing and reaching strategic goals aimed at boosting the performance of Ukrainian exporters and promoting their products on foreign markets. The inefficiency of state incentives for encouraging Ukrainian producers to export goods and services is a serious problem, as is the lack of financing for exporters and a significant level of corruption. They block any positive initiatives to promote goods and services of Ukrainian enterprises in foreign markets, including countries of the Middle East.

Thus, Ukraine ensures the expansion of export of goods and services to existing markets, development of new markets, as well as transparency of trade conditions and predictability of trade flows through participation in international specialized organizations, dialogue with partner countries and the activities of Ukrainian export-credit agency. The main elements of the strategy for institutional support of Ukraine's foreign trade with the Middle East have been defined. The main goals of this strategy entail creating conditions for financial support of exporters and regulatory support of the strategy, using of tariff and non-tariff regulation mechanisms, strengthening the integrated institutional framework to stimulate innovation, developing the innovative potential of enterprises, and optimizing the economic and legal environment for export operations. Taking into account the results of this study, the authors intend to focus their further developments in this scientific field on the analysis of the macroeconomic, political, legal, sociocultural and technological environment in the Middle East.

\section{References}

Abdouli, M., \& Hammami, S. (2020). Economic growth, environment, FDI inflows, and financial development in Middle East countries: Fresh evidence from simultaneous equation models. Journal of the Knowledge Economy, 11(2), 479-511.

Askari, H. (2007). Middle East oil exporters: what happened to economic development? Edward Elgar Publishing. 
Bohomolov, O. V., Danylov, S. I., Havrylenko, N., Bobrovytskyi, A., Parakhonskyi, B., Yavorska, H., Yuldashev, R., \& Palamarchuk, M. (2020.) Middle East and North Africa as Ukraine's sphere of interest: Analytical report (O. V. Lytvynenko, ed.) [in Ukrainian]. National Institute of Strategic Studies. https://niss.gov.ua/sites/default/files/2020-07/e-book_orient_complete.indd_.pdf

Bohorodytska, H., Hrytsenko A., \& Voitov, S. (2020). Foreign economic relations of Ukraine and the Middle East countries [in Ukrainian]. Economic Scope, 156, 26-31. https://doi.org/10.32782/2224-6282/156-4

Bureiko, N., Maksak H., \& Shelest, H. (Eds.). (2020). Ukrainian prism: Foreign policy 2019. Analytical study [in Ukrainian]. PO «Rada zovnishnioii polityky «Ukrainska pryzma», Fond im. F. Eberta. http://library.fes.de/pdffiles/bueros/ukraine/16141.pdf

Éltető, A. \& Antalóczy, K. (2017). Export promotion aims and reality: A comparison of the Iberian, Baltic and Central European region. TalTech Journal of European Studies, 7(1), 43-63. https://doi.org/10.1515/bjes-2017-0004.

Glasser, B. L. (2001). Economic development and political reform: The impact of external capital on the Middle East. Edward Elgar Publishing.

Hasan, A. E. A. (2018). Jordan and Ukraine: The main areas of cooperation [in Russian]. Science initiative "Universum», 115-117.

Kamianetska, O. (2016). The system of state support of exporters in developed countries. Eastern Europe: economics, business and management, 2, 37-41.

Kupchenko A., \& Rozhko, V. (2020). Ukraine supplies every fifth tonne of grains to the Middle East - APK-Inform. APK-Inform Agency. https://www.apkinform.com/en/exclusive/topic/1507200

Mashal, A. M. (2012). The financial crisis of 2008-2009 and the Arab states economies. International Journal of Business and Management, 7(4), 96112. https://doi.org/10.5539/ijbm.v7n4p96

Mazaraki, A., Melnichenko, S., \& Duginets, G. (2018). Ukrainian economy growth imperatives. Coretex CZ SE.

Mazaraki, A. A., Melnyk, T. M., \& Yukhymenko V. V. (2014). Strategy of postcrisis development of foreign economic sector of Ukraine: monograph (A. A. Mazaraki, Ed.) [in Ukrainian]. Kyiv National University of Trade and Economics.

Metcalfe, B., \& Mimouni, F. (Eds.). (2011). Leadership development in the Middle East. Edward Elgar Publishing.

Milton-Edwards, B. (2018). Contemporary politics in the Middle East (4th ed.). John Wiley \& Sons.

Ministry of Foreign Affairs of Ukraine. (n.d.). https://mfa.gov.ua 
Ministry of Foreign Affairs of Ukraine. (2020). Dmytro Senik: we are introducing a new format of consultations to support Ukrainian exporters [in Ukrainian]. https://mfa.gov.ua/news/dmitro-senik-zaprovadzhuyemo-novij-format-konsultacijdlya-pidtrimki-ukrayinskih-eksporteriv

Muhammad, B. (2019). Energy consumption, CO2 emissions and economic growth in developed, emerging and Middle East and North Africa countries. Energy, 179, 232-245.

Nebaba, N., \& Kolpina, A. (2020). Features of the liberalization of trade-economic cooperation between Ukraine and the Middle East countries [in Ukrainian]. Journal «Ekonomika ta derzhava», 4, 210-214. https://doi.org/ 10.32702/2306-6806.2020.4.210

Omar, I. O. (2013). Prospects of economic co-operation of Ukraine and the Middle East countries [in Russian]. Business Inform, 3, 64-69.

Order of the Cabinet of Ministers of Ukraine No. 1017-p of December 12, 2017 «On approving the Export Strategy of Ukraine («road map» of strategic development of trade) for 2017-2021» [in Ukrainian]. https://zakon.rada.gov.ua/laws/show/1017-2017-\%D1\%80\#Text

Order of the President of Ukraine No. 522/2010 of April 8, 2010 «On some aspects of representing economic interests of Ukraine abroad» [in Ukrainian]. https://zakon.rada.gov.ua/laws/show/522/2010\#Text.

Order of the President of Ukraine No. 837 of November 8, 2019 «On urgent measures to conduct reforms and strengthen the state» [in Ukrainian]. https://zakon.rada.gov.ua/laws/show/837/2019\#Text.

Santosa, D. B. (2018). Does export promotion policy benefit for ASEAN economic development? International Journal of Trade and Global Markets, 11(1-2), 3-11. https://doi.org/10.1504/IJTGM.2018.092484

Sharov, O. (2019). Economic diplomacy: fundamentals, problems and prospects: monograph [in Ukrainian]. National Institute for Strategic Studies.

State Institution «Export Promotion Office of Ukraine». (n.d,). https://epo.org.ua/about

State Statistics Service of Ukraine. (n.d.). http://www.ukrstat.gov.ua.

Verkhovna Rada of Ukraine. (2012, May 17). The Verkhovna Rada of Ukraine adopted the Law "On State Financial Support of Export Activities» [in Ukrainian]. https://www.rada.gov.ua/news/Povidomlennya/61623.html

Wnukowski, D. (2016). Export Promotion Agency: The experience of selected European countries. Polski Instytut Spraw Międzynarodowych 